\title{
DANILO KIŠ
}

\section{Kendsgerningernes prøvesten}

\author{
Schizopsykologi
}

"Den moderne form for fantastik er erudition" er det blevet sagt i forbindelse med Borges, hvis jeg ikke husker fejl. Denne korte konstatering indeholder imidlertid hele den moderne litteraturs poetik, og jeg vil mene, at en sådan formulering $i$ virkeligheden er grundlaget for hele den moderne litteratur. Hvad er det man ønsker at sige med denne formel? At tiden for at udtænke ting er forbi, at læseren ikke mere tror på fantasterier, for den moderne tid og konstellationen af den "globale landsby", der mangfoldiggør virkelighedens bizarre kendsgerninger, har vist, at Dostojevskis famøse udsagn, at "intet er mere fantastisk end virkeligheden", ikke bare er et fikst indfald hos en forfatter, men at virkelighedens fantastik har åbenbaret sig for det moderne menneske som den fantastiske virkelighed. Det spøgelsesagtige billede af en by som et månelandskab med to hundrede tusind døde og forvredne menneskekroppe i ufatteligt omfang er et syn som en middelalderlig forfatters fantasi (trods alt) kun kunne forestille sig ved hjælp af en uhørt dristig indbildningskraft og det kun uden for denne verden, i de fjerne egne, hvor der straffes og sones. Hiroshima er midtpunktet $\mathrm{i}$ denne fantastiske verden, hvis omrids kunne skimtes under første verdenskrig, da rædslen i de hemmelige selskaber begyndte at blive til virkelighed som et rituelt masseoffer på ideologiens, guldkalvens, religionens alter... Jeg siger "de hemmelige selskaber", for der er tale om okkultisme: mængden af opsparet ondskab og virkelighedens rå fantastik kan ikke udelukkende fortolkes med historiske og psykologiske kendsgerninger, men snarere med det, MacLean og Koestler efter homo sapiens' paranoide adfærd kalder schizofysiologi, hvis logiske konsekvens er schizopsykologien. Og på et litterært plan er det heller ikke tilstrækkeligt med de såkaldte psykologiske tilgange, der bygger på dichotomien godt og ondt eller på moralske kategorier som de ti guds bud eller de syv dødssynder, som mennesker slås med: allegorien, den vel nok ældste af alle kunstneriske (først og fremmest litterære) indgange til mennesket og verden (hvis yderste konsekvens i kunsten er den såkaldte psykologi), har vist sig uegnet i fortolkningen af menneskets paranoide adfærd. Med en sådan erkendelse nærmer en forfatter sig ikke sine helte for at fortolke deres handlinger ud fra overtrædelsen af et forbud eller ud fra moralske konsekvenser, men prøver som Truman Capote i bogen In Cold Blood at samle en mængde af de dokumenter og kendsgerninger, hvis vanvittige og uforudsigelige kobling skaber en absurd massakre, hvori indgår sociologiske, etnologiske, parapsykologiske okkulte og lignende motiver, som det ville være mere end meningsløst at fortolke på en gammeldags manér, for bag det altsammen ligger menneskets schizopsykologiske 
adfærd, den paranoide, dvs. den fantastiske virkelighed: det er forfatterens pligt at fiksere denne paranoide virkelighed, at undersøge dette sindssyge spil af omstændigheder med styrke fra dokumenter, undersøgelser og en forskningsmetode og ikke på egen hånd og vilkårligt at forsøge at give en diagnose og foreslå en kur og en medicin.

\section{Den psykologiske metode}

Den psykologiske metode er som oftest banaliteternes tumleplads, og forfatteren en dilletant sui generis der med hele sit talents styrke skal forestille at afdække årsagerne til det onde (Både i den sociale og den psykologiske sfære) og foreslå radikale løsninger, selv om disse løsninger kun suggereres implicit. Billig (forfatter)psykologi fører på det moralske plan almindeligvis til billige løsninger: forfatteren bliver enten ikonofil eller ikonoklast (ligegyldigt hvilket af de to) inden for rammerne af de eksisterende kræfter: kirke, nationalisme, ideologi eller okkultisme.

\section{"Materiale til udformning af sujet'et"}

Fortællingerne om Boris Davidovič og andre i bogen En grav til Boris Davidovič krævede mere eller mindre, at oplysningerne kom for "kendsgerningernes prøvesten", som fru Yourcenar ville have sagt. Og det vil sige: i stedet for vilkårligt fantasteri (for der er tale om et historisk tema og historiske personer, der undertiden optræder under eget navn, undertiden som foto-robotter) at henholde sig til dokumenter og historiske kendsgerninger, frem for alt på fabel- planet. "Fablen er i virkeligheden kun materiale til udformning af sujet'et" - Sklovski). At tænke sig ( $f$. eks.) at en soldat i den spanske republikanske hær bliver kidnappet og ført til en sovjettisk fangelejr ville $\mathrm{i}$ dag og set fra et nutidigt synspunkt være tænkeligt: en mængde kendsgerninger og historiske beviser taler for en sådan antagelse. Men når man tager det følsomme ved et sådant tema i betragtning, det vil sige tænker på den dybt forankrede og skinsygt bevogtede forfængelighed hos et stort antal intellektuelle, og her tænker jeg først og fremmest på de såkaldt venstreorienterede intellektuelle $\mathrm{i}$ vesten, der ikke ønsker at se bestemte kendsgerninger $\mathrm{i}$ øjnene, fordi de kunne fremkalde så stærke rystelser i deres sind og føre til en nødvendig revision af deres ungdoms idealer (dengang alt var klart som solen), - når man altså tager en sådan følsomhed og en sådan psykologisk blindhed i betragtning, var det nødvendigt $i$ valget af temaer for min novellecyklus at benytte mig af fabler hvis autenticitet der ikke kunne sættes spørgsmålstegn ved.

\section{Obsessive temaer}

At være professionel forfatter her og nu, dvs. at have litteratur som eneste lidenskab og kald, betyder at leve i bestandig konflikt med sig selv og med omverdenen. Med sig selv fordi enhver anden beskæftigelse, ligegyldigt om den på den ene eller den 
anden måde er komplementær med litteraturen, forekommer én at være et forræderi mod ens holdning og talent, at være en slags erstatning og spild af tid; som et forræderi mod én selv. Men desværre skriver jeg, trods min klare holdning for litteraturen, ikke som professionel, men som "digter", dvs. at jeg udelukkende beskæftiger mig med mine egne obsessive temaer $\mathrm{i}$ en slags digterisk rus, og vælger kun de temaer og de problemer, der optager mig intimt, dvs. intellektuelt og moralsk eller $i$ en lyrisk symbiose af det intellektuelle og det moralske. Lidt mere enkelt sagt, har jeg ikke på forhånd valgt noget tema efter en eller anden bestseller-logik, "dagens tema-logik" eller et tema efter bestilling, men sætter mig til bords i det sjældne øjeblik (der bliver sjældnere og sjældnere), hvor glasset er blevet fyldt til randen, hvor et intellektuelt, moralsk eller lyrisk dilemma eller min tvivl er vokset så stærkt, at jeg føler behov for at meddele det til nogen. Det er årsagen til min beskedne bibliografi, fem-seks bøger, det er årsagen til, at de er så relativt korte, trods den evidente kendsgerning, at det er bøger, der er skrevet af en "erfaren pen", dvs. af en kompetent hånd. Det forekommer mig, at både værkernes korthed (typisk for moderne forfattere) og deres fragmentarisme netop er en følge af denne "digteriske tilgang" til virkelighedens fænomener, for denne i virkeligheden lyriske procedé tåler ikke episk bredde ("begejstringen er kortvarig"). Hvis der i en sådan holdning er noget, der er værd at respektere, er det i første række den kendsgerning, at en kompetent forfatter hverken kan eller vil (af højere moralske grunde) beskæftige sig med litteratur som profession, trods proklamerede og argumenterede principper, trods en klar holdning for litteraturen som "det daglige brød".

Mine første bøger, også den såkaldte "familiecyklus" opstod af en ungdommelig (trods alt) søgen efter svar på lyriske og metafysiske spørgsmål: hvor kommer jeg fra? hvem er jeg? hvor går jeg hen? spørgsmål, der på grund af nogle uklare og skæbnesvangre omstændigheder (race-miljø-moment) stadig er åbne og uklare, også efter at bøgerne er skrevne, men for mig uden smerte og ikke mere aktuelle: jeg har i mine bøger i stedet for at give svar stillet mig selv nye spørgsmål, og har befriet mig for det lyriske tryk på en ganske gammeldags og tilsyneladende effektiv måde: ved at tappe blod fra pulsåren på det sted, hvor trykket var størst; den langvarige pine holdt op og jeg har følt mig befriet som efter et mareridt eller en seance på en psykoanalytiker-charlatans divan. Virkeligheden (de skrevne bøger) erstattede fiktionen i de kvalfulde spørgsmål.

Også En grav til Boris Davidovič er opstået efter en lignende (uprofessionel) metode, dvs. som følge af et obsessivt tema; at have været vidne til to repressive systemer, to blodige historiske virkeligheder, to systemers udryddelseslejre og så kun at skrive om ét af dem (fascismen), og overse det andet (stalinismen) som en psykologisk blind plet - det var en obsessiv, intellektuel tanke, en moralsk og moralistisk kval, der i den sidste tid trykkede mig så meget, at jeg måtte ty til at "tappe det lyriske blod" fra pulsåren. Efter at have været igennem mængder af litteratur, hovedsagelig af ikke-skønlitterær art om Stalins udrensninger og lejre, voksede den obsessive tanke til flovhed og skamfuldhed; vi opfører os næsten allesammen som Pavlovs hunde, vores betingede reflekser er stadig den eneste sande spiritus movens for vores lyriske og episke (litterære) handlinger, vi savler som hunde ved lyden af dødsklokker og ved Auschwitzorkesterets danse macabre, og vores betingede reflek- 
ser $\mathrm{i}$ adfærd og tænkemåde dikterer det, der er det farligste for litteraturen, nemlig at vi gentager stereotype tænkemåder, holdninger, figurer, relationer. Da denne tanke havde nået sin lyriske tyngde, da den var vokset til flovhed og skam, til erkendelse, begyndte jeg at skrive mine historier $i$ en slags digterisk krampe, relativt let og hurtigt, som når man ryster en ond drøm af sig og gennemstrømmet af en følelse af velvære (trods temaet). Det var en form for åndelig lettelse, som måske kun de virkelige syndere føler efter skriftemålet på dødslejet.

\section{Hunde og bøger}

Alt det andet, alt det, der fulgte var kun prisen for skaberglæden: hele den vanvittige ståhej, forfatterne, angiverne og farisæerne, der forsøgte og stadig forsøger at finde frem til meningen med og bevæggrundene til min utilstedelige optræden, dette mit projekt, dette mit opgør med de klichéer, der havde sløvet deres sporhundesnuders skarphed, og i stedet for at æde det kød, der var inden for rækkevidde mistede de alle deres (pavlovske) vaner, og gav sig til at gø og bide, for det er også en del af deres (slumrende) betingede reflekser.

Det velnærede skriverpak (trods en objektiv holdning hos kritikken, eller netop på grund af den, trods læserne og nogle få velmenende forfattere) optog min bog som en personlig fornærmelse - hvad den også var, og fattede bogens budskab bedre end jeg havde turdet håbe på; de fandt frem til dens mening og bevæggrunde, de benægtede ethvert moralsk og ideologisk aspekt i den (områder, hvor pakket føler sig som ignoranter). Efter hvad de sagde - for de kan kun tænke i klichéer - var denne bog ikke andet end variationer over temaet "jødernes skæbne" og som sådan perifer, lokal, irrelevant, suspekt.

Men alle disse forfattere, om de nu havde alle fingre $\mathrm{i}$ behold eller ej, om de nu havde "nosser" eller eller ej, om de nu havde munden fuld af søde ord eller ej, havde ret på et eneste punkt: fortællingen om Darmolatov var historien om dem, han var en allegori, i hvilken de havde let ved at genkende sig selv.

"Hundene bjæffer, men karavanen drager videre..."

På dansk ved Per Jacobsen 